\title{
Distribution of Dehalococcoides 16S rRNA and Dehalogenase Genes in Contaminated Sites
}

\author{
Miho Yoshikawa ${ }^{1}$, Mio Takeuchi ${ }^{1} \&$ Ming Zhang $^{1}$ \\ ${ }^{1}$ Geological Survey of Japan, National Institute of Advanced Industrial Science and Technology (AIST), Tsukuba, \\ Japan \\ Correspondence: Ming Zhang, Geological Survey of Japan, National Institute of Advanced Industrial Science and \\ Technology (AIST), Tsukuba, Ibaraki, 305-8567, Japan. Tel: 81-29-861-3943. E-mail: m.zhang@aist.go.jp
}

Received: March 6, 2017

Accepted: March 25, 2017

Online Published: April 11, 2017

doi:10.5539/enrr.v7n2p37

URL: https://doi.org/10.5539/enrr.v7n2p37

\begin{abstract}
Understanding the spatial distribution of Dehalococcoides and its reductive dehalogenase genes in sediment is important for bioremediation of sites contaminated with chlorinated ethylenes. A total of 56 sediment samples were collected from four contaminated sites in Japan, and quantified copies of Dehalococcoides 16S rRNA and reductive dehalogenase genes: $t c e A, b v c A$, and $v c r A$, as well as chlorinated ethylenes. Dehalococcoides was detected from 22 sediment samples with various geological formations, textures and saturation conditions. The detected Dehalococcoides 16S rRNA gene ranged from $6.4 \times 10^{2}$ to $2.5 \times 10^{7}$ copies $\mathrm{g}^{-1}$. In the 22 samples, the dehalogenase genes: $t c e A, b v c A$, and $v c r A$ were contained $1.4 \times 10^{3}$ to $1.6 \times 10^{4}, 1.0 \times 10^{3}$ to $2.0 \times 10^{5}$, and $2.7 \times 10^{2}$ to $8.5 \times 10^{5}$ copies $\mathrm{g}^{-1}$, respectively. Statistical analysis revealed that the distribution of dehalogenase genes depends on site and depth, but not existence of vinyl chloride. To estimate potential for bioremediation of contaminated sites, quantification of dehalogenase genes according to sediment depth is important and thus recommended.
\end{abstract}

Keywords: bioremediation, chlorinated ethylenes, Dehalococcoides, dehalogenase genes, spatial distribution

\section{Introduction}

\subsection{Contaminated Sites with Chlorinated Ethylenes}

Chlorinated ethylenes, such as tetrachloroethylene (PCE) and trichloroethylene (TCE), have been widely used throughout the world as industrial solvents for several decades. Major applications include dry-cleaning, degreasing, refrigeration, lubrication, processing of textiles, and production of chlorofluorocarbons. Given improper handling and/or a lack of adequate regulations, many industrial sites have been contaminated by these solvents (Zhang \& Yoshikawa, 2016). A statistical survey in Japan has estimated that over 130,000 sites may be contaminated by chlorinated ethylenes and that appropriate countermeasures are required for remediation of these polluted sites (GEPC, 2000). In other industrialized countries, such as the United States, the extent of the problem is similar (Moran, Zogorski, \& Squillace, 2007). Most of the hazardous-waste sites in the United States listed in the National Priority List (NPL) are also contaminated by chlorinated ethylenes, including TCE (e.g., US EPA, 2017). The contaminated sites require remediation because chlorinated ethylenes are carcinogenic or probably carcinogenic to humans (IARC, 2016).

\subsection{Biodegradation of Chlorinated Ethylenes}

Bioremediation of sediments contaminated with chlorinated ethylenes is a prospective technology for remediation. This technology has the advantages of being environmentally friendly, cost-effective and applicable in situ (Zhang \& Yoshikawa, 2016). Taking into account concentration rebound of contaminants after remediation of permeable media due to contaminants absorbed onto low permeability media (US EPA, 2013b), bioremediation of whole sediment is necessary.

Under anaerobic conditions, PCE and TCE can be sequentially dechlorinated to produce the intermediate products cis-dichloroethylene (cis-DCE) and vinyl chloride (VC), which can be further dechlorinated to ethylene (e.g., Freedman \& Gossett, 1989; DiStefano, Gossett, \& Zinder, 1991). The by-product VC is of particular concern because it is carcinogenic to humans (Kielhorn, Melber, Wahnschaffe, Aitio, \& Mangelsdorf, 2000), whereas the completely dechlorinated final product, ethylene, is harmless. 
Various genera of microbes, such as Sulfurospirillum (Scholz-Muramatsu, Neumann, Messmer, Moore, \& Diekert, 1995), Desulfitobacterium (Gerritse et al., 1996), Dehalococcoides (Maymó-Gatell, Chien, Gossett, \& Zinder, 1997), Dehalobactar (Holliger et al., 1998), and Geobacter (Sung et al., 2006), are able to dechlorinate PCE and TCE using reductive dehalogenase encoded by pceA, though only Dehalococcoides can completely dechlorinate these compounds to ethylene. Several reductive dehalogenases of Dehalococcoides, including those encoded by the tce A (Magnuson, Romine, Burris, \& Kingsley, 2000), vcrA (Müller et al., 2004), and bvcA (Krajmalnik-Brown et al., 2004) genes, can contribute to dechlorination. TceA dechlorinates TCE to VC, BvcA dechlorinates VC to ethylene, and VcrA dechlorinates cis-DCE to ethylene. In practical remediation, quantitative PCR of the reductive dehalogenase genes in addition to Dehalococcoides 16S rRNA genes can powerfully support the design of a bioremediation plan (ITRC, 2013; US EPA, 2013b). The potential for bioremediation of sites contaminated with chlorinated ethylenes using Dehalococcoides strains can be examined by means of quantitative PCR.

\subsection{Spatial Distributions of Dehalogenase Genes in Sediment}

Quantitative information for reductive dehalogenase genes is a prospective indicator for bioremediation of contaminated sediment, though the spatial distribution of the genes has been clarified mainly in groundwater. Van der Zaan et al. (2010) quantified reductive dehalogenase genes in groundwater samples at 11 sites, and indicated that $t c e A$ and $b v c A$ gene copy numbers correlate with oxidizing conditions, whereas $v c r A$ gene copy number correlates with $\mathrm{VC}$ and other chlorinated ethylene concentrations. Although groundwater samples have been collected at one contaminated site, the presence/absence of reductive dehalogenase genes differed between samples (Mészáros, Imfeld, Nikolausz, \& Nijenhuis, 2013).

\subsection{Object of this Study}

The objective of this study was to enhance our understanding of the spatial distribution of genes encoding reductive dehalogenases as well as Dehalococcoides 16S rRNA in contaminated subsurface environments. We collected 56 sediment samples from four contaminated sites in Japan and subjected the samples to quantitative PCR analyses targeting the 16S rRNA gene of Dehalococcoides in addition to the dehalogenase genes $t c e A, v c r A$, and $b v c A$, the most important indicators of ethylene formation and necessary information for judging whether complete biodegradation of PCE, TCE and/or cis-DCE would be possible or not.

\section{Method}

\subsection{Sampling Locations}

Samples were collected from four sites originally contaminated with PCE. These sites were located in Tokyo (site A), Chiba prefecture (sites B and C), and Osaka (site D) in Japan (Figure 1). Preliminary investigations at these sites showed the presence of TCE, cis-DCE and VC, indicating that these sites were considered to be undergoing sequential reductive dechlorination.

Site A was a vacant lot formerly occupied by a dry-cleaning plant in a coastal area. The entire surface of the vacant lot was covered by the concrete foundation of the former plant. The groundwater level at site A was $-1.9 \mathrm{~m}$. Core boring was performed at five locations (Aa to Ae) located 10-20 m apart. Site B was a yard next to an old, small dry-cleaning plant located in an inland area. The groundwater level at site B was $-1.3 \mathrm{~m}$. Core boring was performed at two locations ( $\mathrm{Ba}$ and $\mathrm{Bb}$ ), both downstream of the plant and $1 \mathrm{~m}$ apart from each other. Site $\mathrm{C}$ was a vacant lot formerly occupied by a plant producing PCE that was built on reclaimed land in a coastal area. The groundwater level at site $\mathrm{C}$ was $-0.9 \mathrm{~m}$. Core boring was performed at two locations $(\mathrm{Ca}$ and $\mathrm{Cb})$, which were 60 $\mathrm{m}$ apart from each other. Site $\mathrm{D}$ was a metal-processing plant, with a groundwater level of $-2.8 \mathrm{~m}$. Core boring was performed at one location (Da), which was $380 \mathrm{~m}$ away from a high concentration source of contamination on the downstream side of the plant.

\subsection{Sediment Sampling}

Sediment samples were taken from undisturbed, boring cores drilled at the above sites. The boring cores were classified by texture, namely as alluvium sandy soil (AS), alluvium silt (AM), alluvium peat (APt), reclaimed sand (RS), reclaimed silt (RM), embankment sand (ES) and embankment silt (EM) (Table 1). The 56 samples categorized by texture were treated as sediment samples. The samples were used for microbial analysis and detection of chlorinated ethylenes. For microbial analysis, $20 \mathrm{ml}$ of each sediment sample were placed in a sterile tube from the center of the sample. For detection of chlorinated ethylenes, $10 \mathrm{~g}$ of each sediment sample was placed in a nominal $100 \mathrm{ml}$ glass crimp vial filled with $100 \mathrm{ml}$ ultrapure water, and the vials were sealed immediately with rubber septa and aluminum caps at the collection site. All samples were chilled during transportation below $4{ }^{\circ} \mathrm{C}$. The sediment samples in tubes for the microbial analysis were stored in a freezer at - 
$20{ }^{\circ} \mathrm{C}$, while the sediment samples in vials for the detection of chlorinated ethylenes were stored at $4{ }^{\circ} \mathrm{C}$ until laboratory analyses.

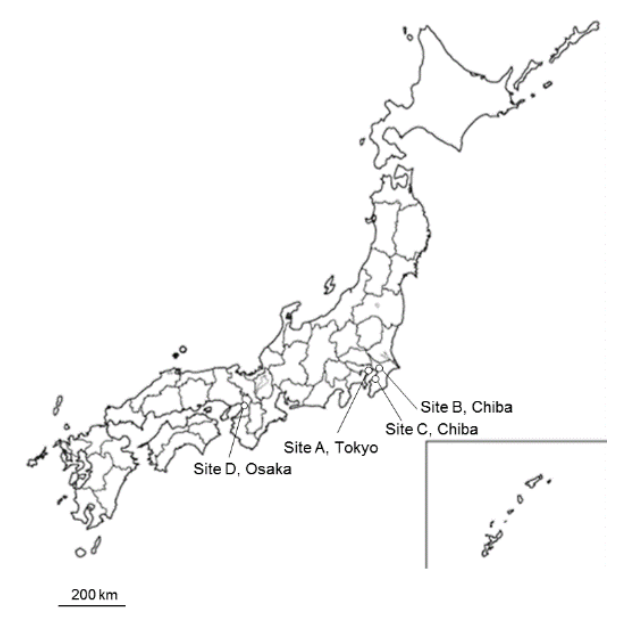

Figure 1. Location of Sampling Sites in This Study

Table 1. Sediment Samples Taken from Four Sites Contaminated with Chlorinated Ethylenes in Japan

\begin{tabular}{|c|c|c|c|c|c|c|c|c|}
\hline Sample & & Depth(m) & Sediment classification & & ample & & Depth(m) & Sediment classification \\
\hline \multirow{7}{*}{$\mathrm{Aa}$} & 1 & 0.2 & EM & \multirow{7}{*}{ Site B } & $\mathrm{Ba}$ & 1 & 1.3 & EM \\
\hline & 2 & 1.4 & $\mathrm{AM}$ & & & 2 & 1.5 & $\mathrm{APt}$ \\
\hline & 3 & 1.7 & AS & & & 3 & 1.8 & $\mathrm{APt}$ \\
\hline & 4 & 5.3 & AS & & & & & \\
\hline & 5 & 7.8 & AS & & $\mathrm{Bb}$ & 1 & 1.3 & EM \\
\hline & 6 & 8.7 & $\mathrm{AM}$ & & & 2 & 1.5 & $\mathrm{APt}$ \\
\hline & 7 & 11.8 & $\mathrm{AM}$ & & & 3 & 1.8 & $\mathrm{APt}$ \\
\hline \multirow[b]{9}{*}{ Site A } & 1 & 0.6 & EM & \multirow{14}{*}{ Site C } & $\mathrm{Ca}$ & 1 & 0.2 & ES \\
\hline & 2 & 1.6 & $\mathrm{AM}$ & & & 2 & 0.7 & ES \\
\hline & 3 & 2.6 & AS & & & 3 & 1.4 & EM \\
\hline & 4 & 5.6 & AS & & & 4 & 2.4 & RS \\
\hline & 5 & 7.8 & AS & & & & & \\
\hline & 6 & 8.5 & $\mathrm{AM}$ & & $\mathrm{Cb}$ & 1 & 0.4 & ES \\
\hline & 7 & 9.5 & $\mathrm{AM}$ & & & 2 & 0.8 & ES \\
\hline & 8 & 10.3 & $\mathrm{AM}$ & & & 3 & 1.4 & RS \\
\hline & & & & & & 4 & 2.4 & RS \\
\hline \multirow[t]{9}{*}{ Ac } & 1 & 0.4 & EM & & & 5 & 3.6 & RS \\
\hline & 2 & 1.3 & $\mathrm{AM}$ & & & 6 & 9.3 & $\mathrm{RM}$ \\
\hline & 3 & 2.7 & AS & & & 7 & 9.8 & RS \\
\hline & 4 & 5.7 & AS & & & 8 & 10.8 & RS \\
\hline & 5 & 7.9 & AS & & & & & \\
\hline & 6 & 8.7 & $\mathrm{AM}$ & \multirow{10}{*}{ Site D } & $\mathrm{Da}$ & 1 & 0.7 & EM \\
\hline & 7 & 9.7 & $\mathrm{AM}$ & & & 2 & 1.5 & $\mathrm{AM}$ \\
\hline & 8 & 10.6 & $\mathrm{AM}$ & & & 3 & 1.6 & $\mathrm{AM}$ \\
\hline & & & & & & 4 & 2.7 & AS \\
\hline \multirow[t]{4}{*}{$\mathrm{Ad}$} & 1 & 5.7 & AS & & & 5 & 3.3 & AS \\
\hline & 2 & 7.9 & $\mathrm{AM}$ & & & 6 & 4.7 & AS \\
\hline & 3 & 8.9 & $\mathrm{AM}$ & & & 7 & 5.7 & AS \\
\hline & & & & & & 8 & 6.6 & AS \\
\hline \multirow[t]{2}{*}{$\mathrm{Ae}$} & 1 & 5.7 & AS & & & 9 & 7.6 & $\mathrm{AM}$ \\
\hline & 2 & 8.9 & $\mathrm{AM}$ & & & 10 & 8.7 & $\mathrm{AM}$ \\
\hline
\end{tabular}

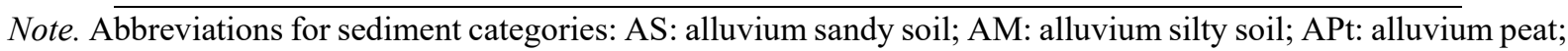
RS: reclaimed sand; RM: reclaimed silt; ES: embankment sand; EM: embankment silt. Groundwater level at sites $\mathrm{A}, \mathrm{B}, \mathrm{C}$, and D was $-1.9 \mathrm{~m},-1.3 \mathrm{~m},-0.9 \mathrm{~m}$ and $-2.8 \mathrm{~m}$, respectively. 
The sediment sample for microbial analysis was homogenized and mixed in the tube, followed by DNA extraction from $0.5 \mathrm{~g}$ of the sediment sample. The DNA was extracted with the FastDNA ${ }^{\text {TM }}$ SPIN Kit for Soil (Q-BIO Gene, Irvine, CA, USA) (Yoshikawa, Zhang, \& Toyota, 2017). When the sediment sample was applied to the kits, 20 mg skim milk was added to increase the efficiency of DNA extraction (Takada-Hoshino \& Matsumoto 2004; Yoshikawa et al., 2017).

\subsection{Quantitative PCR}

We performed quantitative PCR on the DNA extracts to determine the number of 16S rRNA gene copies from bacteria in general and from strains of the bacterial genus Dehalococcoides. When a sample contained the Dehalococcoides 16S rRNA gene, we also quantified the copy number of the reductive dehalogenase genes $t c e A$, $b v c A$, and $v c r A$ in the sample. Bacterial 16S rRNA was quantified using the primers BAC338F and BAC805R, and the probe BAC516F (Yu, Lee, Kim, \& Hwang, 2005). We used primers and probes specific for the Dehalococcoides 16S rRNA gene published by Freeborn et al. (2005). To assay reductive dehalogenase genes, specific primers and probe were used: the primers TceA1270F and TceA1336R and the quenching antisense probe TceA1294 (Johnson, Lee, Holmes, \& Alvarez-Cohen, 2005) for tceA; the primers Bvc925F and Bvc1017R and the antisense probe Bvc977 (Ritalahti et al., 2006) for $b v c A$; and the primers Vcr1022F and Vcr1093R and antisense probe Vcr1042 (Ritalahti et al., 2006) for $v c r A$. PCR amplification and quantification were performed using an ABI PRISM 7000 Sequence Detection System (Thermo Fisher Scientific, Waltham, MA, USA) for bacterial and Dehalococcoides 16S rRNA genes, and Rotor-Gene Q (QIAGEN, Venlo, Netherland) for the reductive dehalogenase genes. Detection limits of gene copies in DNA extract for both bacterial and Dehalococcoides $16 \mathrm{~S}$ rRNA were $1.1 \times 10^{1}$ copies/uL. The limits for all kinds of reductive dehalogenase genes were $1.0 \times 10^{0}$ copies/uL. All quantitative PCR assays were performed at least three times in each DNA extract to ensure the reproducibility and quality of the data.

\subsection{Cluster Analysis for Reductive Dehalogenase Genes}

To categorize the sediment samples with numbers of reductive dehalogenase genes, cluster analysis was performed using the numbers transformed logarithmically. When the reductive dehalogenase gene was not detected in a sample, the quantity 0.001 was used for descriptive purposes. The software R 3.3.2 (R Core Team, 2016) and the R package vegan 2.4-1 (Oksanen et al., 2016) were used to analyze the data. Bray-Curtis similarity coefficients were calculated based on the reductive dehalogenase genes data, and cluster analysis of the similarity coefficients using the unweighted pair-group method with arithmetic means (UPGMA) was used to construct a dendrogram.

\subsection{Analysis of Chlorinated Ethylenes}

Chlorinated ethylenes in the sediment samples were analyzed by the headspace gas chromatography/mass spectrometry (GC/MS) method. The sediment samples sealed within the nominal $100 \mathrm{ml}$ glass crimp vials containing $100 \mathrm{ml}$ water were stirred for $4 \mathrm{~h}$. A $10 \mathrm{ml}$ aliquot of the slurry was sampled with a syringe and transferred to a $10 \mathrm{ml}$ glass crimp vial that was sealed with a rubber septum and an aluminum cap in advance. Headspace volume of the nominal $10 \mathrm{ml}$ glass crimp vial was $3 \mathrm{ml}$. A gas sample was taken from the headspace within the $10 \mathrm{ml}$ glass crimp vial containing the sediment slurry. The gas sample was analyzed for concentration of chlorinated ethylenes with a GC/MS (6890, Agilent, Santa Clara, CA, USA) installed with a column (DB-5ms, Agilent).

\section{Results}

\subsection{Numbers of Microbial 16S rRNA Genes and Reductive Dehalogenase Genes}

The sediment samples contained $6.7 \times 10^{4}$ to $4.5 \times 10^{8}$ copies $\mathrm{g}^{-1}$ of bacterial $16 \mathrm{~S}$ rRNA genes (Table 2). Dehalococcoides 16S rRNA gene was detected from 22 sediment samples at sites A, B, and C. Dehalococcoides 16S rRNA gene was not detected from any samples at site D. The samples in which the Dehalococcoides $16 \mathrm{~S}$ rRNA gene was detected had $6.4 \times 10^{2}$ to $2.5 \times 10^{7}$ copies $\mathrm{g}^{-1}$ of the gene, whereas the number of bacterial $16 \mathrm{~S}$ rRNA genes in the samples ranged from $1.2 \times 10^{5}$ to $9.8 \times 10^{7}$ copies $\mathrm{g}^{-1}$. The reductive dehalogenase genes $t c e A$, $b v c A$, and $v c r A$ were detected from three, 15, and 11 samples, respectively, among the 22 sediment samples that contained Dehalococcoides. The numbers of the dehalogenase genes were $1.4 \times 10^{3}$ to $1.6 \times 10^{4} \mathrm{copies}^{-1}$ for tce $A, 1.0 \times 10^{3}$ to $2.0 \times 10^{5}$ copies $\mathrm{g}^{-1}$ for $b v c A$, and $2.7 \times 10^{2}$ to $8.5 \times 10^{5}$ copies $^{-1}$ for $v c r A$, respectively. 
Table 2. Numbers of Microbial 16S rRNA Genes and Reductive Dehalogenase Genes Detected by Quantitative PCR in the Sediment Samples

\begin{tabular}{|c|c|c|c|c|c|c|c|c|c|c|c|c|c|}
\hline \multicolumn{2}{|c|}{ Sample } & \multirow{2}{*}{$\frac{\text { Bacteria }}{7.8 \times 10^{6}}$} & \multirow{2}{*}{$\frac{\mathrm{DHC}}{1.6 \times 10^{4}}$} & \multirow{2}{*}{$\frac{t c e A}{\text { n.d. }}$} & \multirow{2}{*}{$\frac{b v c A}{\text { n.d. }}$} & \multirow{2}{*}{$\frac{v c r A}{\text { n.d. }}$} & \multicolumn{2}{|c|}{ Sample } & \multirow{2}{*}{$\frac{\text { Bacteria }}{4.0 \times 10^{8}}$} & \multirow{2}{*}{$\frac{\text { DHC }}{\text { n.d. }}$} & \multirow{2}{*}{$\frac{t c e A}{-}$} & \multirow{2}{*}{$\frac{b v c A}{-}$} & \multirow{2}{*}{$\frac{v c r A}{-}$} \\
\hline $\mathrm{Aa}$ & 1 & & & & & & $\mathrm{Ba}$ & 1 & & & & & \\
\hline & 2 & $8.7 \times 10^{6}$ & $1.9 \times 10^{5}$ & n.d. & $3.9 \times 10^{4}$ & $4.3 \times 10^{3}$ & & 2 & $1.3 \times 10^{5}$ & n.d. & - & - & - \\
\hline & 3 & $5.1 \times 10^{6}$ & $1.3 \times 10^{5}$ & n.d. & $9.3 \times 10^{3}$ & $4.3 \times 10^{2}$ & & 3 & $1.3 \times 10^{6}$ & n.d. & - & - & - \\
\hline & 4 & $3.7 \times 10^{6}$ & $5.5 \times 10^{5}$ & n.d. & $5.3 \times 10^{4}$ & $1.1 \times 10^{3}$ & & & & & & & \\
\hline & 5 & $4.5 \times 10^{6}$ & $7.3 \times 10^{5}$ & n.d. & $3.1 \times 10^{4}$ & n.d. & $\mathrm{Bb}$ & 1 & $9.6 \times 10^{6}$ & n.d. & - & - & - \\
\hline & 6 & $5.5 \times 10^{6}$ & n.d. & - & - & - & & 2 & $4.5 \times 10^{8}$ & n.d. & - & - & - \\
\hline & 7 & $6.1 \times 10^{5}$ & n.d. & - & - & - & & 3 & $9.8 \times 10^{7}$ & $1.4 \times 10^{4}$ & n.d. & $8.6 \times 10^{3}$ & $1.4 \times 10^{3}$ \\
\hline \multirow[t]{9}{*}{$\mathrm{Ab}$} & 1 & $1.1 \times 10^{6}$ & n.d. & - & - & - & $\mathrm{Ca}$ & 1 & $6.3 \times 10^{7}$ & n.d. & - & - & - \\
\hline & 2 & $8.0 \times 10^{5}$ & $1.3 \times 10^{4}$ & n.d. & $1.0 \times 10^{4}$ & $9.9 \times 10^{3}$ & & 2 & $7.5 \times 10^{6}$ & n.d. & - & - & - \\
\hline & 3 & $2.4 \times 10^{5}$ & $2.1 \times 10^{5}$ & n.d. & $2.0 \times 10^{5}$ & $5.9 \times 10^{4}$ & & 3 & $7.2 \times 10^{5}$ & $1.7 \times 10^{3}$ & $1.6 \times 10^{4}$ & $3.5 \times 10^{3}$ & $8.4 \times 10^{3}$ \\
\hline & 4 & $2.3 \times 10^{5}$ & $1.1 \times 10^{4}$ & n.d. & $2.8 \times 10^{4}$ & n.d. & & 4 & $1.3 \times 10^{6}$ & $2.6 \times 10^{5}$ & $1.4 \times 10^{3}$ & $2.3 \times 10^{4}$ & $8.5 \times 10^{5}$ \\
\hline & 5 & $2.4 \times 10^{5}$ & $5.3 \times 10^{4}$ & n.d. & n.d. & n.d. & & & & & & & \\
\hline & 6 & $2.5 \times 10^{5}$ & $1.5 \times 10^{4}$ & n.d. & $1.0 \times 10^{3}$ & $2.7 \times 10^{2}$ & $\mathrm{Cb}$ & 1 & $3.8 \times 10^{7}$ & n.d. & - & - & - \\
\hline & 7 & $3.8 \times 10^{5}$ & n.d. & - & - & - & & 2 & $1.5 \times 10^{7}$ & n.d. & - & - & - \\
\hline & 8 & $3.1 \times 10^{5}$ & n.d. & - & - & - & & 3 & $2.0 \times 10^{7}$ & n.d. & - & - & - \\
\hline & & & & & & & & 4 & $1.1 \times 10^{5}$ & n.d. & - & - & - \\
\hline \multirow[t]{9}{*}{$\mathrm{Ac}$} & 1 & $2.5 \times 10^{7}$ & n.d. & - & - & - & & 5 & $2.7 \times 10^{7}$ & $1.6 \times 10^{4}$ & $9.3 \times 10^{3}$ & n.d. & n.d. \\
\hline & 2 & $5.8 \times 10^{5}$ & $3.4 \times 10^{4}$ & n.d. & $6.5 \times 10^{4}$ & $2.8 \times 10^{4}$ & & 6 & $6.7 \times 10^{6}$ & n.d. & - & - & - \\
\hline & 3 & $3.1 \times 10^{5}$ & $1.7 \times 10^{4}$ & n.d. & $2.9 \times 10^{4}$ & $5.3 \times 10^{4}$ & & 7 & $6.3 \times 10^{5}$ & n.d. & - & - & - \\
\hline & 4 & $2.4 \times 10^{5}$ & $6.4 \times 10^{2}$ & n.d. & $1.8 \times 10^{3}$ & n.d. & & 8 & $3.7 \times 10^{5}$ & n.d. & - & - & - \\
\hline & 5 & $1.2 \times 10^{5}$ & $1.9 \times 10^{3}$ & n.d. & n.d. & n.d. & & & & & & & \\
\hline & 6 & $2.9 \times 10^{5}$ & n.d. & - & - & - & $\mathrm{Da}$ & 1 & $1.2 \times 10^{8}$ & n.d. & - & - & - \\
\hline & 7 & $2.3 \times 10^{5}$ & n.d. & - & - & - & & 2 & $2.0 \times 10^{7}$ & n.d. & - & - & - \\
\hline & 8 & $7.0 \times 10^{5}$ & n.d. & - & - & - & & 3 & $1.1 \times 10^{7}$ & n.d. & - & - & - \\
\hline & & & & & & & & 4 & $4.8 \times 10^{6}$ & n.d. & - & - & - \\
\hline \multirow[t]{4}{*}{$\mathrm{Ad}$} & 1 & $2.1 \times 10^{5}$ & $6.1 \times 10^{4}$ & n.d. & $2.1 \times 10^{4}$ & n.d. & & 5 & $6.5 \times 10^{6}$ & n.d. & - & - & - \\
\hline & 2 & $3.3 \times 10^{5}$ & $2.4 \times 10^{5}$ & n.d. & n.d. & n.d. & & 6 & $6.7 \times 10^{4}$ & n.d. & - & - & - \\
\hline & 3 & $7.3 \times 10^{7}$ & $2.5 \times 10^{7}$ & n.d. & n.d. & n.d. & & 7 & $1.5 \times 10^{5}$ & n.d. & - & - & - \\
\hline & & & & & & & & 8 & $1.2 \times 10^{5}$ & n.d. & - & - & - \\
\hline \multirow[t]{2}{*}{$\mathrm{Ae}$} & 1 & $3.8 \times 10^{7}$ & $2.2 \times 10^{7}$ & n.d. & n.d. & n.d. & & 9 & $1.9 \times 10^{6}$ & n.d. & - & - & - \\
\hline & 2 & $9.9 \times 10^{5}$ & n.d. & - & - & - & & 10 & $1.3 \times 10^{6}$ & n.d. & - & - & - \\
\hline
\end{tabular}

Note. The unit for number in the sediment sample is copies $\mathrm{g}^{-1}$. DHC: Dehalococcoides 16S rRNA gene; n.d.: under detection limit; -: not tested.

\subsection{Similarity in Reductive Dehalogenase Genes}

The cluster analysis divided the 22 sediment samples in which Dehalococcoides was detected into five clusters on the basis of variation in reductive dehalogenase genes present (Figure 2). Clusters 1 to 3 comprised sediment samples in which $b v c A$ was detected. In addition to $b v c A$, the samples grouped in Cluster 2 contained tce $A$ and $v c r A$, and those in Cluster 3 contained $v c r A$. The sediment samples Ab3, Ac2 and Ac3 contained a higher number of $v c r A\left(\geq 2.8 \times 10^{4}\right.$ copies $\left.\mathrm{g}^{-1}\right)$ than other samples grouped in the same cluster. Cluster 4 contained one sample $\mathrm{Cb} 5$, in which tceA was detected. Cluster 5 comprised six sediment samples in which none of the three reductive dehalogenase genes was detected.

\subsection{Presence of PCE and Its By-products}

The presence of PCE, and its by-products TCE, cis-DCE and VC, was detected from all of the boring cores (Table 3). Among the total of 56 sediment samples, 38 samples contained VC. Aa1, the surface sample from boring core $\mathrm{Aa}$, contained $\mathrm{VC}$, whereas $\mathrm{Ab} 1$ and $\mathrm{Ac1}$, the surface samples of the $\mathrm{Ab}$ and Ac boring cores, did not contain detectable VC. Among samples from the B site, VC was detected at $1.8 \mathrm{~m}$ depth (Ba3 and $\mathrm{Bb} 3)$. VC was present throughout the Ca core at $0.2-2.4 \mathrm{~m}$ depth $(\mathrm{Ca} 1-4)$, though the $\mathrm{Cb}$ core contained $\mathrm{VC}$ at deeper layers from 3.6 to $10.8 \mathrm{~m}$ (Cb5-8). In the Da boring core, VC existed at deep layers from 4.7 to $8.7 \mathrm{~m}$ (Da6-10), whereas VC was not detected in the upper layers. 


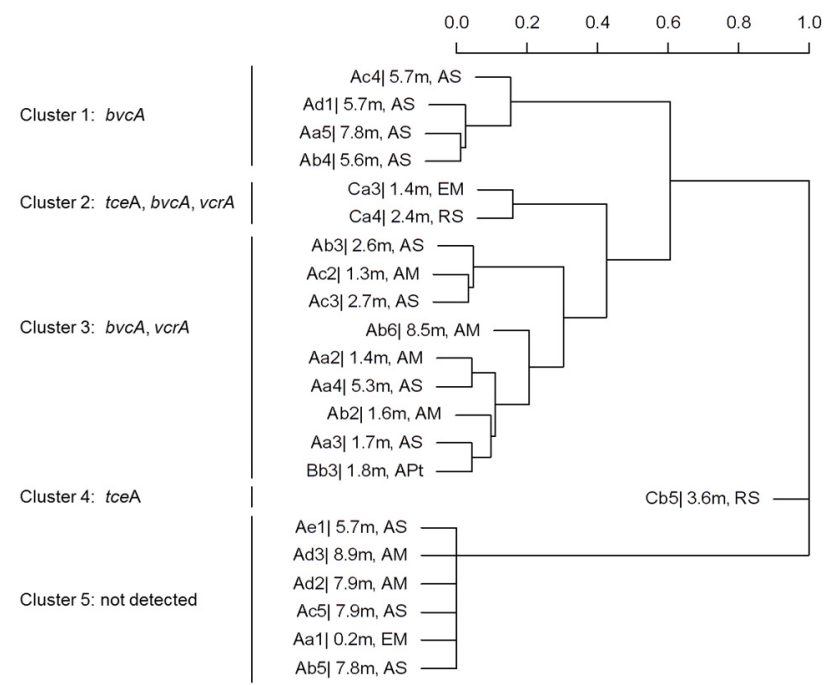

Figure 2. Cluster Analysis of Reductive Dehalogenase Genes Detected in the Sediment Samples

Note. The dendrogram was constructed from an UPGMA cluster analysis for similarity in the reductive dehalogenase genes between sediment samples. The scale units are the Bray-Curtis similarity coefficient. Abbreviations after the cluster number indicate the reductive dehalogenase gene detected from the sediment sample. Abbreviations for dehalogenase genes: tceA: encoding TceA which dechlorinates TCE to VC; $b v c A$ : encoding BvcA which dechlorinates VC to ethylene; $v c r A$ : encoding VcrA which dechlorinates cis-DCE to ethylene.

Table 3. Detection of Chlorinated Ethylenes in Sediment Samples

\begin{tabular}{|c|c|c|c|c|c|c|c|c|c|c|c|}
\hline \multicolumn{2}{|c|}{ Sample } & \multirow[t]{2}{*}{ PCE } & \multirow[t]{2}{*}{ TCE } & \multirow[t]{2}{*}{ cis-DCE } & \multirow{2}{*}{$\frac{\mathrm{VC}}{+}$} & \multicolumn{2}{|c|}{ Sample } & \multirow{2}{*}{$\frac{\text { PCE }}{+}$} & \multirow{2}{*}{$\frac{\text { TCE }}{+}$} & \multirow{2}{*}{$\frac{c i s-\mathrm{DCE}}{+}$} & \multirow[t]{2}{*}{$\mathrm{VC}$} \\
\hline $\mathrm{Aa}$ & 1 & & & & & $\mathrm{Ba}$ & 1 & & & & \\
\hline & 2 & & & + & + & & 2 & + & + & + & \\
\hline & 3 & & & & + & & 3 & & + & + & + \\
\hline & 4 & + & & & + & & & & & & \\
\hline & 5 & & & + & + & $\mathrm{Bb}$ & 1 & + & + & + & \\
\hline & 6 & & & & + & & 2 & & + & + & \\
\hline & 7 & & & & & & 3 & & & + & + \\
\hline \multirow[t]{9}{*}{$\mathrm{Ab}$} & 1 & & & & & $\mathrm{Ca}$ & 1 & + & + & + & + \\
\hline & 2 & & & & + & & 2 & + & + & + & + \\
\hline & 3 & & & & + & & 3 & + & + & + & + \\
\hline & 4 & + & & & + & & 4 & + & + & + & + \\
\hline & 5 & + & + & + & + & & & & & & \\
\hline & 6 & + & + & + & + & $\mathrm{Cb}$ & 1 & + & + & & \\
\hline & 7 & + & & + & + & & 2 & + & + & & \\
\hline & 8 & + & + & + & + & & 3 & + & + & & \\
\hline & & & & & & & 4 & + & & & \\
\hline \multirow[t]{9}{*}{ Ac } & 1 & + & + & + & & & 5 & & & & + \\
\hline & 2 & + & + & + & & & 6 & + & + & + & + \\
\hline & 3 & + & + & & & & 7 & + & + & + & + \\
\hline & 4 & + & + & + & + & & 8 & + & + & + & + \\
\hline & 5 & + & + & + & + & & & & & & \\
\hline & 6 & + & + & + & + & $\mathrm{Da}$ & 1 & & & & \\
\hline & 7 & + & & + & + & & 2 & & & & \\
\hline & 8 & + & & + & + & & 3 & & & & \\
\hline & & & & & & & 4 & & & & \\
\hline \multirow[t]{4}{*}{$\mathrm{Ad}$} & 1 & + & + & + & & & 5 & + & + & + & \\
\hline & 2 & + & + & + & + & & 6 & + & + & + & + \\
\hline & 3 & + & + & + & + & & 7 & + & + & + & + \\
\hline & & & & & & & 8 & + & + & + & + \\
\hline \multirow[t]{2}{*}{$\mathrm{Ae}$} & 1 & + & + & + & + & & 9 & + & + & + & + \\
\hline & 2 & + & + & + & + & & 10 & + & & + & + \\
\hline
\end{tabular}

Note. + Chlorinated ethylenes were detected at a concentration $>0.001 \mathrm{mg}^{-1}$ in sediment slurries.

\section{Discussion}




\subsection{Habitable Geological Environment for Dehalococcoides}

Dehalococcoides existed in various geological environments that differed in geological formation, sedimentary texture, and saturation condition (Table 1,2). Geological formations in which the Dehalococcoides 16S rRNA gene was detected included naturally formed alluvium, artificially created embankment, and reclaimed land. Dehalococcoides spreads beneath sediments derived from different processes of formation. Dehalococcoides forms tiny disc-shaped cells of $0.3-1 \mu \mathrm{m}$ diameter and $0.1-0.2 \mu \mathrm{m}$ thick, but its motility has not been determined (Löffler et al., 2013). Weiss, Mills, Hornberger, and Herman (1995) indicated that smaller and rounder-shaped bacteria are more easily transported through the soil column. Therefore, Dehalococcoides cells are likely to be easily transported through the sediment with groundwater flow.

Sedimentary textures of the samples in which the Dehalococcoides 16S rRNA gene was detected included sand, silt, and peat. This finding coincided with a previous study in which Dehalococcoides was detected not only in sandy sediments but also in silty and clay sediments (Takeuchi et al., 2011). Dehalococcoides cells in peat sediment may obtain an electron donor and/or carbon source from the peat as suggested in a column study with peat (Mondal et al., 2016). These studies support the contention that Dehalococcoides can inhabit sediments of a variety of textures.

Dehalococcoides existed in the Aa1 deposit in the unsaturated zone at site A (groundwater level-1.9 m; Tables 1, 2), though Dehalococcoides is known to be an obligately anaerobic bacteria (Löffler et al., 2013). The existence in the Aal sample might be explained by protection from oxygen exposure by concrete and soil particles. Concrete pavement reduces oxygen infiltration into the soil (Viswanathan, Volder, Watson, \& Aitkenhead-Peterson, 2011). Yoshikawa et al. (2017) showed successful degradation of chlorinated ethylenes to harmless ethylene by Dehalococcoides after exposure to oxygen when soil particles existed in the test environment.

In situ bioremediation has been performed mainly on groundwater rather than sediment (US EPA 2013a). However, the present results indicate that bioremediation with Dehalococcoides also may be suitable for diverse sediment types.

\subsection{Relationships between Dehalococcoides and VC Existence}

Detection of VC did not always accompany the presence of Dehalococcoides in the present study, though VC has been used as an indicator of Dehalococcoides existence (Demarest, 2014). At site A, VC existed at deeper AM samples in which Dehalococcoides was not detected (Tables 2, 3; Aa6, Ab7-8, Ac6-8, and Ae2). The AS sample, the upper layer of the AM, contained both VC and Dehalococcoides, which implies that dechlorination by Dehalococcoides probably occurred in the AS layer. Mass transport in a silty layer depends on diffusion rather than advection (Domenico \& Schwartz, 1990). Therefore, the detection of VC in the deeper AM samples may be caused by diffusion from the upper layer, or undetectable numbers of the Dehalococcoides 16S rRNA gene.

At sites C and D, VC together with PCE, TCE and cis-DCE were detected in deeper sandy sediments that did not contain Dehalococcoides (Cb7-8 and Da6-8). Layers with sand generally show high permeability (Heath, 1983). Thus, mass transports easily occur compared with silty layers, and contaminants potentially would move long distances from the source through layers with high permeability. The $\mathrm{VC}$ detection at sites $\mathrm{C}$ and $\mathrm{D}$ may be explained by VC transportation from different locations in which chlorinated ethylenes were dechlorinated by Dehalococcoides. Thus, it is essential to consider not only the existence of VC, but also diffusion from an upper layer and advection in a permeable layer, when existence of Dehalococcoides in sediment is estimated.

\subsection{Spatial Distribution of Reductive Dehalogenase Genes}

The reductive dehalogenase genes analyzed were spatially distributed, i.e. the existence of Dehalococcoides possessing similar dehalogenase genes was dependent on site and sedimentary depth (Figure 2). The gene tceA was detected at site $\mathrm{C}$, but not at sites A and $\mathrm{B}$. At sites A and B, the two dehalogenase genes $b v c A$ and $v c r A$ were detected, and 11 samples contained both genes and four samples contained only $b v c A$. The samples at site A were grouped into three clusters, namely Clusters 1,3, and 5. Samples grouped in Cluster 3 were from deposits at 1.3 to $5.3 \mathrm{~m}$ depth except for Ab6, and the samples contained both $b v c A$ and $v c r A$. Samples grouped in Cluster 1 included only $b v c A$, and were deposited at lower depths than samples in grouped in Cluster 3 . None of the dehalogenase genes analyzed were detected in samples grouped in Cluster 5 , which consisted of samples deposited at depths below those grouped in Cluster 1 and a surface sample (Aa1). Previous studies demonstrate that Dehalococcoides has multiple reductive dehalogenase genes in addition to tceA, bvcA, and $v c r A$ (Pöritz et al., 2013; Wang, Chng, Chen, Bedard, \& He, 2015). Therefore, the samples grouped in Cluster 5 may have contained dehalogenase genes other than the three genes tested in the present study. 
Relationships between the reductive dehalogenase genes and chlorinated ethylenes were not indicated. Van der Zaan et al. (2010) demonstrated a positive relationship between numbers of vcrA and VC. However, the sediment samples Ac2 and Ac3, which showed a high number of vcrA, did not contain VC in the present study (Tables 2, 3). Takeuchi et al. (2011) suggested that complete degradation of chlorinated ethylenes occurs in organic-rich sediment. Numbers of reductive dehalogenase genes in sediment might be affected by multiple chemical properties, such as natural organic matter, and not only VC concentration.

Estimation of qualitative and quantitative information on reductive dehalogenase genes is difficult based on the concentrations of chlorinated ethylenes. When degradability of chlorinated ethylenes in sediment is predicted, detection of dehalogenase genes with consideration of sedimentary depth by quantitative PCR would be necessary.

\section{Conclusion}

Quantitative analysis of Dehalococcoides 16S rRNA gene copies in sediment has identified habitable environments for Dehalococcoides, which include sediments artificially formed, composed of silt, and laid in the unsaturated zone. Detection of VC does not always accompany that of Dehalococcoides. The reductive dehalogenase genes $t c e A, b v c A$, and $v c r A$ are spatially distributed, i.e. Dehalococcoides with similar dehalogenase genes exist at a site and specific sedimentary depths. The results suggest that bioremediation with Dehalococcoides is applicable in a variety of environments. Furthermore, quantitative analysis of reductive dehalogenase genes is more informative than analysis of $\mathrm{VC}$ concentration for estimation of the degradability of chlorinated ethylenes.

\section{Acknowledgments}

This research was partially supported by Chemical Grouting Co., LTD. The authors would like to express their sincere appreciation to the support.

\section{References}

Demarest, L. (2014). Soil composition at the aquifer level, groundwater quality and the presence of Dehalococcoides ethenogenes at Dover AFB. Environmental Earth Sciences, 71, 4157-4164. https://doi.org/10.1007/s12665-013-2806-0

DiStefano, T. D., Gossett, J. M., \& Zinder, S. H. (1991). Reductive dechlorination of high concentrations of tetrachloroethene to ethene by an anaerobic enrichment culture in the absence of methanogenesis. Applied and Environmental Microbiology, 57, 2287-2292.

Domenico, P. A., \& Schwartz, F. W. (1990). Physical and Chemical Hydrogeology. New York: John Wiley \& Sons.

Freeborn, R. A., West, K. A., Bhupathiraju, V. K., Chauhan, S., Rahm, B. G., Richardson, R. E., \& Alvarez-Cohen, L. (2005). Phylogenetic analysis of TCE-dechlorinating consortia enriched on a variety of electron donors. Environmental Science \& Technology, 39, 8358-8368. https://doi.org/10.1021/es048003p

Freedman, D. L., \& Gossett, J. M. (1989). Biological reductive dechlorination of tetrachloroethylene and trichloroethylene to ethylene under methanogenic conditions. Applied and Environmental Microbiology, 55, 2144-2151.

Geo-Environmental Protection Center (GEPC). (2000). Prediction of the cost for countermeasures against soil pollutions in our country. Tokyo: Geo-Environmental Protection Center. (In Japanese).

Gerritse, J., Renard, V., Pedro Gomes, T. M., Lawson, P. A., Collins, M. D., \& Gottschal, J. C. (1996). Desulfitobacterium sp. strain PCE1, an anaerobic bacterium that can grow by reductive dechlorination of tetrachloroethene or ortho-chlorinated phenols. Archives of Microbiology, 165, 132-140. https://doi.org/10. 1007/s002030050308

Heath, R. C. (1983). Basic ground-water hydrology. Water Supply Paper 2220, Reston: U.S. Geological Survey.

Holliger, C., Hahn, D., Harmsen, H., Ludwig, W., Schumacher, W., Tindall, B., ... Zehnder, A. J. B. (1998). Dehalobacter restrictus gen. nov. and sp. nov., a strictly anaeobic bacterium that reductively dechlorinates tetra- and trichloroethene in an anaerobic respiration. Archives of Microbiology, 169, 313-321. https://doi.org/10.1007/s002030050577

International Agency for Research on Cancer (IARC). (2016). Agents classified by the IARC Monographs, Volumes 1-117. Lyon: IARC. Retrieved from Retrieved from http://monographs.iarc.fr/ENG/ Classification/List_of_Classifications.pdf 
Interstate Technology and Regulatory Council (ITRC). (2013). Environmental Molecular Diagnostics Fact Sheets. EMD-2. Washington, DC: Interstate Technology \& Regulatory Council, Environmental Molecular Diagnostics Team. Retrieved from http://www.itrcweb.org/GuidanceDocuments/EMD1.pdf

Johnson, D. R., Lee, P. K. H., Holmes, V. F., \& Alvarez-Cohen, L. (2005). An internal reference technique for accurately quantifying specific mRNAs by real-time PCR with application to the $t c e A$ reductive dehalogenase gene. Applied and Environmental Microbiology, 71, 3866-3871. https://doi.org/10.1128/AEM. 71.7.38663871.2005

Kielhorn, J., Melber, C., Wahnschaffe, U., Aitio, A., \& Mangelsdorf, I. (2000). Vinyl chloride: still a cause for concern. Environmental Health Perspectives, 108, 579-588. https://doi.org/10.1289/ehp.00108579

Krajmalnik-Brown, R., Hölscher, T., Thomson, I. N., Saunders, F. M., Ritalahti, K. M., \& Löffler, F. E. (2004). Genetic identification of a putative vinyl chloride reductase in Dehalococcoides sp. strain BAV1. Applied and Environmental Microbiology, 70, 6347-6351. https://doi.org/10.1128/AEM.70.10.6347-6351.2004

Löffler, F. E., Yan, J., Ritalahti, K. M., Adrian, L., Edwards, E. A., Konstantinidis, K. T., ... Spormann, A. M. (2013). Dehalococcoides mccartyi gen. nov., sp. nov., obligately organohalide-respiring anaerobic bacteria relevant to halogen cycling and bioremediation, belong to a novel bacterial class, Dehalococcoidia classis nov., order Dehalococcoidales ord. nov. and family Dehalococcoidaceae fam. nov., within the phylum Chloroflexi. International Journal of Systematic and Evolutionary Microbiology, 63, 625-635. https://doi.org/10.1099/ijs.0.034926-0

Magnuson, J. K., Romine, M. F., Burris, D. R., \& Kingsley, M. T. (2000). Trichloroethene reductive dehalogenase from Dehalococcoides ethenogenes: Sequence of tceA and substrate range characterization. Applied and Environmental Microbiology, 66, 5174-5147. https://doi.org/10.1128/aem.66.12.5141-5147.2000

Maymó-Gatell, X., Chien, Y., Gossett, J. M., \& Zinder, S. H. (1997). Isolation of a bacterium that reductively dechlorinates tetrachloroethene to ethene. Science, 276, 1568-1571. https://doi.org/10.1126/science.276. 5318.1568

Mészáros, É., Imfeld, G., Nikolausz, M., \& Nijenhuis, I. (2013). Occurrence of Dehalococcoides and reductive dehalogenase genes in microcosms, a constructed wetland and groundwater from a chlorinated ethene contaminated field site as indicators for in situ reductive dehalogenation. Water, Air, and Soil Pollution, 224, 1768. https://doi.org/10.1007/s11270-013-1768-x

Mondal, P. K., Lima, G., Zhang, D., Lomheim, L., Tossell, R. W., Patel, P., \& Sleep, B. E. (2016). Evaluation of peat and sawdust as permeable reactive barrier materials for stimulating in situ biodegradation of trichloroethene. Journal of Hazardous Materials, 313, 37-48. https://doi.org/10.1016/j.jhazmat.2016.03.049

Moran, M. J., Zogorski, J. S., \& Squillace, P. J. (2007). Chlorinated solvents in groundwater of the United States. Environmental Science \& Technology, 41, 74-81. https://doi.org/10.1021/es061553y

Müller, J. A., Rosner, B. M., Von Abendroth, G., Meshulam-Simon, G., McCarty, P. L., \& Spormann, A. M. (2004). Molecular identification of the catabolic vinyl chloride reductase from Dehalococcoides sp. strain VS and its environmental distribution. Applied and Environmental Microbiology, 70, 4880-4888. https://doi.org/10.1128/AEM.70.8.4880-4888.2004

Oksanen, J., Blanchet, F. G., Friendly, M., Kindt, R., Legendre, P., McGlinn, D., Minchin, P. R., ... Wagner, H. (2016). vegan: Community Ecology Package. R package version 2.4-1. Retrieved from https://CRAN. Rproject.org/package $=$ vegan

Pöritz, M., Goris, T., Wubet, T., Tarkka, M. T., Buscot, F., Nijenhuis, I., ... Adrian, L. (2013). Genome sequences of two dehalogenation specialists - Dehalococcoides mccartyi strains BTF08 and DCMB5 enriched from the highly polluted Bitterfeld region. FEMS Microbiology Letters, 343:101-104. https://doi.org/10.1111/15746968.12160

R Core Team. (2016). R: A language and environment for statistical computing. $R$ Foundation for Statistical Computing. Vienna, Austria. Retrieved from https://www.R-project.org/

Ritalahti, K. M., Amos, B. K., Sung, Y., Wu, Q., Koenigsberg, S. S., \& Löffler, F. E. (2006). Quantitative PCR targeting 16S rRNA and reductive dehalogenase genes simultaneously monitors multiple Dehalococoides strains. Applied and Environmental Microbiology, 72, 2765-2774. https://doi.org/10.1128/AEM.72.4.2765 2774.2006 
Scholz-Muramatsu, H., Neumann, A., Messmer, M., Moore, E., \& Diekert, G. (1995). Isolation and characterization of Dehalospirillum multivorans gen. nov., sp. nov., a tetrachloroethene-utilizing, strictly anaerobic bacterium. Archives of Microbiology, 163, 48-56. https://doi.org/10.1007/BF00262203

Sung, Y., Fletcher, K. E., Ritalahti, K. M., Apkarian, R. P., Ramos-Hernandez, N., Sanford, R. A., ... Löffler, F. E. (2006). Geobacter lovleyi sp. nov. strain SZ, a novel metal-reducing and tetrachloroethene-dechlorinating $\begin{array}{lllll}\text { bacterium. } \quad \text { Applied and Environmental } & \text { Microbiology, }\end{array}$ https://doi.org/10.1128/AEM.72.4.2775-2782.2006

Takada-Hoshino, Y., \& Matsumoto, N. (2004). An improved DNA extraction method using skim milk from soils that strongly adsorb DNA. Microbes and Environments, 19, 13-19. https://doi.org/10.1264/jsme2.19.13

Takeuchi, M., Kawabe, Y., Watanabe, W., Oiwa, T., Takahashi, M., Nanba, K., ... Komai T. (2011). Comparative study of microbial dechlorination of chlorinated ethenes in an aquifer and a clayey aquitard. Journal of Contaminant Hydrology, 124, 14-24. http://doi.org/10.1016/j.jconhyd.2011.01.003

United States Environmental Protection Agency (US EPA). (2013a). Superfund Remedy Report. 14th ed. Washington, DC: United States Environmental Protection Agency, Washington, DC, EPA 542-R-13-016.

United States Environmental Protection Agency (US EPA). (2013b). Introduction to In Situ Bioremediation of Groundwater. Washington, DC: United States Environmental Protection Agency. EPA 542-R-13-018.

United States Environmental Protection Agency (US EPA). (2017, February 23). In Superfund: National Priorities List (NPL). Retrieved from Februrary 23, 2017, from https://www.epa.gov/superfund/superfund -nationalpriorities-list-npl

van der Zaan, B., Hannes, F., Hoekstra, N., Rijnaarts, H., de Vos, W. M., Smidt, H., \& Gerritse, J. (2010). Correlation of Dehalococcoides $16 \mathrm{~S}$ rRNA and chloroethene-reductive dehalogenase genes with geochemical condition in chloroethene-contaminated groundwater. Applied and Environmental Microbiology, 76, 843-850. https://doi.org/10.1128/AEM.01482-09

Viswanathan, B., Volder, A., Watson, W. T., \& Aitkenhead-Peterson, J. A. (2011). Impervious and pervious pavements increase soil $\mathrm{CO}_{2}$ concentrations and reduce root production of American sweetgum (Liquidambar styraciflua). Urban Forestry \& Urban Greening, 10, 133-139. http://doi.org/10.1016/j.ufug. 2011.01.001

Wang, S., Chng, K. R., Chen, C., Bedard, D. L., \& He, J. (2015). Genomic characterization of Dehalococcoides mccartyi strain JNA that reductively dechlorinates tetrachloroethene and polychlorinated biphenyls. Environmental Science \& Technology, 49, 14319-14325. https://doi.org/10.1021/acs.est.5b01979

Weiss, T. H., Mills, A. L., Hornberger, G. M., \& Herman, J. S. (1995). Effect of bacterial cell shape on transport of bacteria in porous media. Environmental Science \& Technology, 29, 1737-1740. https://doi.org/10.1021/ es $00007 \mathrm{a} 007$

Yoshikawa, M., Zhang, M., \& Toyota, K. (2017). Integrated anaerobic-aerobic biodegradation of multiple contaminants including chlorinated ethylenes, benzene, toluene and dichloromethane. Water, Air, and Soil Pollution, 228, 25. https://doi.org/doi:10.1007/s11270-016-3216-1

Yu, Y., Lee, C., Kim, J., \& Hwang, S. (2005). Group-specific primer and probe sets to detect methanogenic communities using quantitative real-time polymerase chain reaction. Biotechnology and Bioengineering, 89, 670-679. https://doi.org/10.1002/bit.20347

Zhang, M., \& Yoshikawa, M. (2016). An overview of remediation technologies for sites contaminated with volatile organic compounds. In N. Yesiller, D. Zekkos, A. Farid, A. De, \& K. R. Reddy (Eds.), Proceedings of GeoChicago 2016: Sustainable Waste Management and Remediation. GSP273. (pp. 295-301) Reston: U.S. ASCE Geotechnical Special Publication. http://doi.org/10.1061/9780784480168.030

\section{Copyrights}

Copyright for this article is retained by the author(s), with first publication rights granted to the journal.

This is an open-access article distributed under the terms and conditions of the Creative Commons Attribution license (http://creativecommons.org/licenses/by/4.0/). 